\title{
The Future of Insurance Supervision in the EU: National Authorities, Lead Supervisors or EU Supranational Institution?
}

\author{
Jan Monkiewicz \\ Politechnika Warszawska, Narbutta 85, PL-02524 Warsaw, Poland. \\ E-mail: g.monkiewicz@neostrada.pl
}

Financial markets require proper regulation and supervision. Their standards, architecture and mutual relations have to keep pace both with the current understanding of the core business as well as with market developments.

The program put forward by FSAP and particularly by the Solvency II project revitalized among other things again the discussion on the future of EU insurance supervision. Should it remain - as of today - largely state based,or should it go into more or less different directions - a lead supervisor or some supranational agency?

The article seeks to review major elements of the current debate and to stress the need for continuity in the possible future evolution of the EU supervisory systems.

The Geneva Papers (2007) 32, 393-400. doi:10.1057/palgrave.gpp.2510133

Keywords: regulation and supervision; regulatory reform; legislation

\section{Introductory remarks}

The growth of the EU financial markets, including insurance, its regulation and supervision over the last decades remains heavily influenced by the concept of the single financial market.

This concept, covering as of today banking, insurance and reinsurance and the securities sectors is a unique and complex idea. It is worthwhile to recall that this concept is based on six core principles developed gradually in the period from 1973 to 1993. They include:

1. national jurisdiction of the member countries,

2. freedom of establishment,

3. freedom of services,

4. minimum harmonization,

5. single licence (passport),

6. home country control.

According to the first principle, each member state bears the sole responsibility for the financial market-related regulations. There are so far practically no EUwide international regulations which directly impact on the regulatory system of the member states. Thus currently the single EU financial market is regulatory-wise an aggregate of 28 national jurisdictions. They include 25 EU member countries 
and three countries of the European Economic Area (Norway, Iceland and Liechtenstein) that acceded to the single market on a contractual and voluntary basis.

According to the second principle, every financial institution is free to establish itself in an area of the single financial market and to carry out its operations from there. In the process of establishment the rule of national treatment is applied.

It can also - according to the third principle - provide its transborder services directly to the customers without having any physical presence at the point of delivery. To make these principles work in a coordinated and effective manner three other core principles have been developed. Instrumental among them is principle number four that of minimum harmonization. Its essence lies in the acceptance by the member countries of some mutually agreed set of minimum regulatory standards to be followed by national jurisdictions in their respective national regulatory practice. National jurisdictions are, as a matter of principle, free to apply more restrictive solutions (for instance, higher prudential regulations) as long as they are not forbidden by the international rules adopted. They are not allowed however to use lower standards unless some derogations are granted expressis verbis.

The implementation of that principle in the regulatory practice of EU countries made it possible to move further and to adopt the idea of a single licensing, that is, the concept according to which one sole authorization in the EU space is sufficient for the entire EU financial market. Accordingly, once authorized in any EU country every financial institution is free to use this authorization (frequently referred to as passport) to establish itself in other EU countries via branches or transacting contracts by means of transborder operations.

Finally, the sixth principle denotes that supervisory powers over the financial institutions are in principle delegated to their home country supervisors, which become responsible for their prudent and sound activities not only at home but also abroad. This could hypothetically mean that each individual national market becomes regulated and supervised by 28 jurisdictions that follow their customers - financial institutions - headquartered on their respective territories. The more business is written by foreign authorized institutions, the less powers rest with the host regulators and supervisors. In the extreme case national host authorities may be practically deleted from the scene. In some EU countries this hypothesis is slowly turning into reality.

To sum up, we may conclude that European legislation on the financial markets is based on a chain relationship of minimum standards, mutual recognition, and competition among rules, that is, "on the idea that given the existing differences among EU countries, each member should recognize the validity of laws, regulations and standards of the other ones." This "competition among rules" also implies that economic agents (or regulated entities) are free to choose the regulatory and solvency regime within the single market, thus constituting a final test of the quality of national regulation and supervision.

\footnotetext{
${ }^{1}$ Cervellati and Fioriti (2006, p. 5).
} 


\section{Recent developments in the national supervisory models of the EU countries}

The shape of the future EU insurance supervisory model will be by and large an outcome of the debate and decisions on the overall architecture of the EU financial market supervision. Therefore, we begin our discussion by reviewing recent developments in this area.

There are currently three different models of financial supervision in force in the EU member states:

- by institutions,

- by objectives,

- unitary (integrated).

The supervision by institutions (by sectors, by markets) reflects in its simplest form the way the regulations are drafted and implemented. This model is based on sectoral distribution of supervisory powers among banking, securities and insurance. ${ }^{2}$ Each intermediary and market has only one supervisory counterpoint. The same model is applicable currently at the EU level for Lamfalussy purposes.

This model is currently practiced in Greece, Spain, Lithuania, Luxembourg and Finland (see Table 1).

Supervision by objectives (functional model, by finalities) is based on the assumption that each market and intermediary is supervised by a few authorities responsible for the specific objectives of regulation such as prudential regulation, market conduct, competition, macro-stability, etc. This kind of model is a rare species in the EU and it has been recently put in place in its classical shape by the Netherlands. It has been practiced also partially for some time in France and Italy.

Unitary supervision (single regulator supervision, centralized model) assumes that one single authority takes over the entire control over the financial market. It is usually responsible for all supervisory objectives. The unitary supervisor model seems to currently dominate the national supervisory landscape in the EU. In the course of the last 7 years it has been applied in 12 member states, so altogether by end 2006 it has been practiced in 14 member states. This trend for centralization explained in principle by the financial market conglomeration and institutional hybridization is a worldwide phenomenon.

\section{Lamfalussy regulatory and supervisory revolution}

The Lamfalussy reform package in the regulation and supervision of the EU financial market in force since 2002 has radically changed the existing legal and institutional system, both with respect to the financial market regulation as well as its supervision.

In the area of regulation probably its most profound characteristic is the high degree of centralization of the rules-making process, among others, by playing down the position of national actors and expanding with the help of comitology the role of

\footnotetext{
${ }^{2}$ Di Giorgio and Di Noia (2000, p. 7).
} 
Table 1 Supervisory structures in the EU member states ${ }^{\mathrm{a}}$

\begin{tabular}{|c|c|c|c|c|c|}
\hline $\begin{array}{l}\text { EU member } \\
\text { states/ } \\
\text { acceding } \\
\text { countries }\end{array}$ & $\begin{array}{c}\text { Sectoral } \\
\text { model }\end{array}$ & $\begin{array}{l}\text { Model by } \\
\text { objectives }\end{array}$ & $\begin{array}{l}\text { Single } \\
\text { supervisor } \\
\text { model }\end{array}$ & $\begin{array}{l}\text { Number of } \\
\text { authorities } \\
\text { responsible for } \\
\text { supervision }^{\mathrm{b}}\end{array}$ & $\begin{array}{c}\text { The national } \\
\text { central bank has } \\
\text { supervisory } \\
\text { tasks or responsililites }\end{array}$ \\
\hline $\mathrm{BE}$ & $X$ & & $X$ & 1 & \\
\hline $\mathrm{CZ}$ & $X$ & & $X$ & 1 & $X$ \\
\hline DK & & & $X$ & 1 & \\
\hline DE & $\mathrm{X}$ & 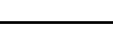 & $\mathrm{X}$ & 1 & $X^{d}$ \\
\hline EE & $X$ & & $X$ & 1 & \\
\hline GR & $X$ & & & 3 & $X$ \\
\hline ES & $X$ & & & 3 & $X$ \\
\hline FR & $X$ & $X$ & & 4 & \\
\hline IE & $X$ & & $\mathrm{X}$ & 1 & \\
\hline IT & $X$ & $X$ & & 4 & $X$ \\
\hline $\mathrm{CY}$ & $X$ & & & 4 & $X$ \\
\hline LV & $X$ & & $X$ & 1 & \\
\hline LT & X & & & 3 & $X$ \\
\hline LU & $X$ & & & 2 & \\
\hline $\mathrm{HU}$ & $X$ & & $X$ & 1 & \\
\hline MT & $X$ & & $X$ & 1 & \\
\hline NL & $X$ & $\rightarrow$ & & 2 & $X$ \\
\hline $\mathrm{AT}$ & $X$ & & $X$ & 1 & $X^{e}$ \\
\hline PL & $X$ & & $\mathrm{X}$ & 1 & \\
\hline PT & $X$ & $X$ & & 3 & $X$ \\
\hline SI & $X$ & & & 3 & $X$ \\
\hline SK & $\mathrm{X}$ & & $X$ & 1 & $X$ \\
\hline FI & $X$ & & & 2 & \\
\hline SE & & & $\mathrm{X}$ & 1 & \\
\hline UK & $X$ & & $X$ & 1 & \\
\hline Total & 10 & 4 & 14 & & 12 \\
\hline BG & $X$ & & & 2 & $X$ \\
\hline RO & $\mathrm{X}$ & & & 4 & $X$ \\
\hline
\end{tabular}

${ }^{a}$ Bulgaria (BG) and Romania (RO), the acceding countries, appear in separate rows. In order to show the evolution of the supervisory structure in each country, different graphic symbols have been used:

$\longrightarrow$ This arrow indicates changes occurring after June 2003

$\longrightarrow$ This arrow indicates changes occurring after 2000 .

In PL, the reforms leading to the single supervisor model will be fully completed by 2008 .

FR, IT and PT appear in both the column "Sectoral model" and in the column "Model by objectives" since they have implemented a combination of the two models.

BG appears in the column "Sectoral model" although the Financial Supervision Commission is in charge of supervising the entire financial market and industry, with the exception of banking activities. The banking supervisory function is entrusted to the Bulgarian National Bank.

${ }^{\mathrm{b}}$ Supervisory authorities with overall responsibility for taking final decisions in their field of competence. ${ }^{\mathrm{c}}$ The column includes central banks which have the responsibility for taking final decisions in the field of banking supervision and central banks (DE, AT) entrusted by law to conduct specific supervisory tasks. In EE, IE and FI, banking supervision is carried out by an independent body which however is part of the central bank.

${ }^{\mathrm{d}}$ In DE, the Deutsche Bundesbank and the supervisory authority (the Bundesanstalt für Finanzdien stleistungsaufsicht, BaFin) are entrusted by law to cooperate closely in the area of banking supervision. In this context, the Deutsche Bundesbank is entrusted by law with ongoing monitoring of institutions.

${ }^{\mathrm{e}}$ The Oesterreichische Nationalbank carries out on-site inspections of banks when commissioned to do so by the FMA (mandatory in the area of credit and market risk), gives expert opinions, and is in charge of processing supervisory reporting data on the basis of which it regularly assesses banks' risks. 
Table 2 Strengths and weaknesses of the Lamfalussy procedure

\begin{tabular}{ll}
\hline Strengths & Weaknesses \\
\hline $\begin{array}{l}\text { Forces supervisory authorities to cooperate, } \\
\text { fostering convergence of supervisory practices }\end{array}$ & $\begin{array}{l}\text { Lacks a clear rule to differentiate between } \\
\text { framework measures and details }\end{array}$ \\
$\begin{array}{l}\text { Fosters "co-opetition" among supervisory } \\
\text { authorities: there is a constructive ambiguity } \\
\text { between regulatory cooperation and competition }\end{array}$ & $\begin{array}{l}\text { Raises questions of what is left for level } \\
3 \text { - standarization? }\end{array}$ \\
$\begin{array}{l}\text { Increases the transparency of the regulatory } \\
\text { process }\end{array}$ & $\begin{array}{l}\text { Tendency towards more centralization: the } \\
\text { European Commission is in the driving seat } \\
\text { and the role of national supervisory authorities }\end{array}$ \\
$\begin{array}{l}\text { Ensures a higher degree of regulatory } \\
\text { harmonization }\end{array}$ & $\begin{array}{l}\text { is limited (to an advisory capacity) } \\
\text { Process is laborious, complex, time- } \\
\text { consuming and resource-absorbing for the } \\
\text { Reduces possibilities for host-country } \\
\text { restrictions }\end{array}$ \\
$\begin{array}{l}\text { authorities as well as for the private sector } \\
\text { Increases the opportunity for regulatory } \\
\text { capture }\end{array}$
\end{tabular}

Source: Lannoo and Casey (2005, p. 7).

the EU Commission, and also by the growing tendency to use maximum harmonization. ${ }^{3}$

In the area of supervision on the other hand the most important result of the Lamfalussy revolution is the new international role assigned to national supervisory authorities and their international supervisory committees. It provides for the first time in the development of the single market for their increased cooperation at all levels of their corporate structures with the aim to achieve regulatory and supervisory convergence. It differs fundamentally from the pre-Lamfalussy situation where the cooperation was largely confined to simple information sharing at national market and financial group levels.

Thus what Lamfalussy revolutionizes is both rules making and their broadly understood implementation process. More unified and speedier regulations should be from now on met with more standardized supervisory policies and approaches (see Table 2).

The Lamfalussy reform is still in its inception and has a long way to go; however, it seems to have started producing already some positive results. Its real testing ground in insurance will be undoubtedly the Solvency II project. The reform is also an example that there are vast areas for improvement in the existing EU national-based regulatory and supervisory system. It is also an example that far reaching reforms of the financial regulations may be introduced not only as an effect of a financial crisis but also beforehand.

\section{Lead supervisors concept}

In contrast to the holistic approach of the Lamfalussy reform, the lead supervisors concept has been generated as the niche solution for the benefit of some regional banking and insurance players organized in the European Financial Services

\footnotetext{
${ }^{3}$ Lannoo and Casey (2005, pp. 8-9).
} 


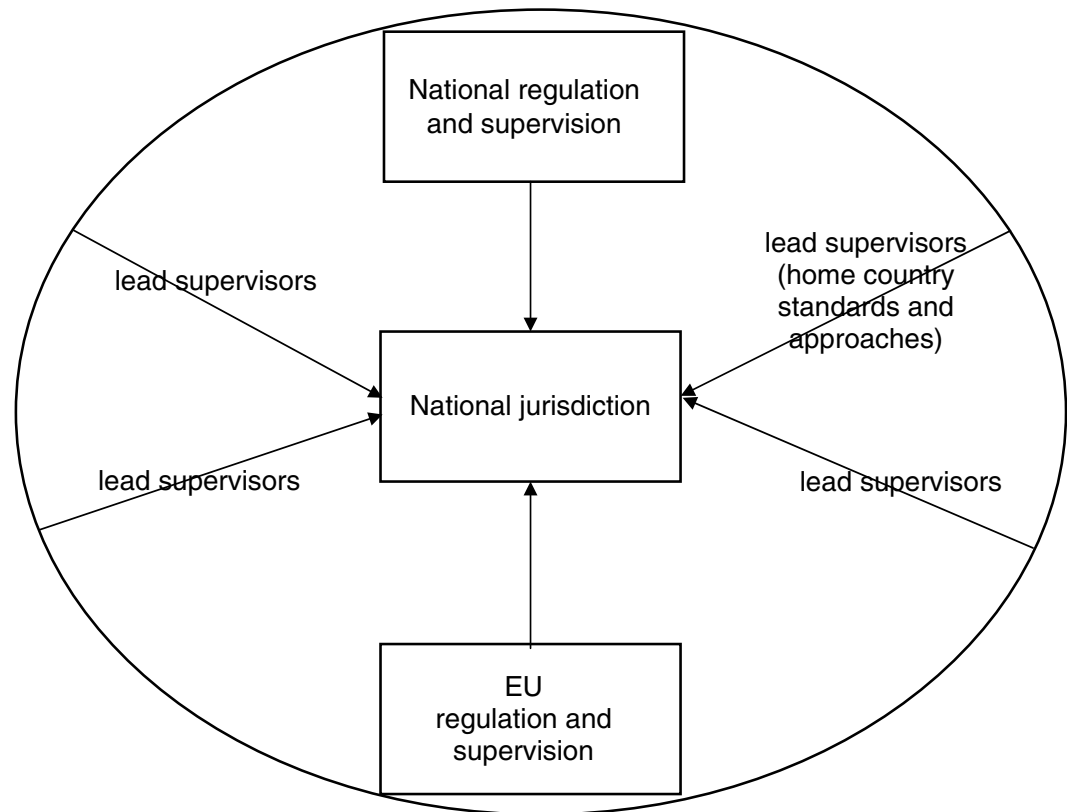

Figure 1. Effects of lead supervisor concept on the design of the national regulatory and supervisory system.

Roundtable (EFR). ${ }^{4}$ It essentially requested an enhancement of the role of the home supervisor to cover the entire prudential supervision over all operations of a financial institution within the EU, including the supervision of its subsidiaries. According to this concept the lead supervisor would: ${ }^{5}$

(a) act as a point of contact for all issues of prudential supervision of a given financial institution,

(b) coordinate reporting duties and decide on its format,

(c) validate internal models in use,

(d) decide on pillar II issues at group level,

(e) approve capital allocation at group level and liquidity rules at group and branch level,

(f) decide upon and coordinate on-site inspections,

(g) coordinate licensing procedures,

(h) act as the EU coordinator vis-à-vis the non-EU home country supervisor.

Implementation of that concept would mean that de facto substantial fragmentation of the financial market regulation and supervision at the national level takes place (see Figure 1).

\footnotetext{
${ }^{4}$ On the lead supervisor model and the future of financial supervision in the EU, see EFR (2005).

${ }^{5}$ Ibid., para 22.
} 
It also means crowding out of national regulation and supervision in proportion to the share of EU-regulated business and replacing it with the "imported" standards. In some countries that could also mean de facto eradication of the local regulation and supervision.

\section{EU supranational authority}

EU supranational authority remains an appealing solution for those who are tired of the current state-based coordination mechanism. ${ }^{6}$ From the strictly technical point of view that might be the simplest case, but politically -as in the United States where insurance jurisdiction has been state based since its inception in the 19th century - it will be difficult to realize before 10-20 years. A precondition would be the convergence of the insurance and administrative laws of the parties concerned because otherwise a single authority would be operating in a multilegal environment and providing more confusion than relief.

\section{Final remarks}

The EU regulatory and supervisory cosmos is experiencing today unprecedented challenges and changes.

In the course of the last few years it has been tested with numerous FSAP measures, Basel II implementation and Lamfalussy reform. It is just facing another spectacular initiative - Solvency II and will be dealing a little bit later with IFRS. All this points to the fact that the existing institutional and legal structures need some time to adapt themselves before delivering. Offering them yet another major reform - that of the supervisory architecture - could be counterproductive. ${ }^{7}$

\section{References}

Cervellati, E.M. and Fioriti, E. (2006) Financial supervision in EU Countries, Working papers series, University of Bologna, January 2.

Di Giorgio, G and Di Noia, C (2000) Designing institutions for financial stability, Universita LUISS and Ministero del Tesoro, November.

European Central Bank (2006) Recent developments in supervisory structures in EU and acceding countries, Frankfurt: ECB, October.

European Financial Services Roundtable (EFR) (2005) On the lead supervisor model and the future of financial supervision in the EU, Follow up recommendations of the EFR, Brussels, Belgium, June.

Gualandri, E. and Grasso, G.A. (2005) Towards a New Approach to Regulation and Supervision in the EU: Post FSAP and Comitology, paper presented at the Annual Conference of European University Teachers in Banking and Finance, London, 31 August-3 September, 2005.

Lannoo, K. and Casey, J.P. (2005) EU financial regulation and supervision beyond 2005, CEPS Task force Report No. 54, January.

Mayes, D.G. (2006) 'Cross-border financial supervision in Europe: Goals and transition paths', Sveriges Riskbank Economic Review 2: 58-89.

\footnotetext{
${ }^{6}$ Mayes (2006, pp. 58-89).

${ }^{7}$ There are of course other views; see in particular Mayes (2006, pp. 58-89).
} 


\section{About the author}

Jan Monkiewicz is Professor of financial management, Department of Production Engineering, Warsaw Technical University, Warsaw, Poland. From 2002 to 2006 he has been Chairman of The Insurance and Pension Funds Supervisory Commission in Poland. Since 2007 he is in charge of the Progres Research Programme of The Geneva Association. 